Research Article

\title{
The effectiveness of problem-based thematic learning module to improve primary school student's critical thinking skills
}

\author{
Anik Twiningsih a,1,* Sajidan a,2, Riyadi a,3 \\ a Department of Primary Education, Faculty of Teacher Training and Education, Universitas Sebelas Maret, Jalan Insinyur Sutami No.36 A \\ Kentingan, Jebres, Surakarta, Central Java, 57126, Indonesia \\ anik.twin@gmail.com*; ${ }^{*}$ sajidan@fkip.uns.ac.id; ${ }^{3}$ yadi_laras@yahoo.com \\ * corresponding author
}

\begin{tabular}{|c|c|}
\hline ARTICLE INFO & ABSTRACT \\
\hline \multirow[t]{2}{*}{$\begin{array}{l}\text { Article history } \\
\text { Received January 26, } 2019 \\
\text { Revised February 14, } 2019 \\
\text { Accepted February 24, } 2019 \\
\text { Published March 06, } 2019\end{array}$} & $\begin{array}{l}\text { Thematic learning is considered as efficient as the students taught learn in coherent } \\
\text { context and holistic way, as well as associate the concepts they learnt with their } \\
\text { surrounding and real-life examples. The aim of the study was to identify the } \\
\text { effectiveness of the problem-based thematic learning module prototype to improve } \\
\text { students' critical thinking skills. This research and development were conducted based } \\
\text { on Borg and Gall model. The module effectiveness was tested using pre-experimental } \\
\text { design. The sampling technique used was cluster random sample which employed as } \\
\text { many as } 33 \text { students in which the data collection technique used was test. The data } \\
\text { gained was analyzed using paired sample t-test. The results showed that the students' } \\
\text { post-test score of critical thinking skills were significantly differed from their pre-test } \\
\text { score. Therefore, the developed module can improve student critical thinking skills } \\
\text { effectively. Moreover, it is suggested that teacher should apply a mixed method of } \\
\text { teaching as it helps to strengthen students' critical thinking skills. }\end{array}$ \\
\hline & $\begin{array}{l}\text { Copyright } \odot ~ 2019, \text { Twiningsih et al } \\
\text { This is an open access article under the CC-BY-SA license }\end{array}$ \\
\hline $\begin{array}{l}\text { cite: Twiningsih } \\
\text { improve pri } \\
\text { https://doi.c }\end{array}$ & $\begin{array}{l}\text { S., \& Riyadi, R. (2019). The effectiveness of problem-based thematic learning module } \\
\text { dent's critical thinking skills. JPBI (Jurnal Pendidikan Biologi Indonesia), 5(1), 117-126. d } \\
\text { oi.v5i1.7539 }\end{array}$ \\
\hline
\end{tabular}

\section{INTRODUCTION}

Teachers have realized that developing of science and technology in industry 4.0 era has an impact on changes in teaching resources and methodologies. Considerable attention is now being paid to developing teaching materials and recognizing the importance of teaching resources and strategies used to maximize the ignition of learning objectives. Teachers need to use resources to deliver instruction. The resource used by the teacher is generally referred to as teaching material (Saglam, 2011). Teaching materials can support student learning and improve student success. Teaching materials give opportunities for students to make predictions and judgments, think intuitively, get motivated, do experiments, and extract formulas from these experiments depending on the results (Koparan, 2017; Saglam, 2011; Williams \& Williams, 2011). The 
number of sensing organs activated by the teaching materials used in the learning-teaching process is directly proportional to an easy and enduring learning process (Saglam, 2011).

Learning materials must be chosen appropriately in order to achieve the learning objectives (both content and competence) of students. Learning materials come in various shapes and sizes; one of them is a module. A module is part of the learning materials developed by using the based principle of teaching materials (Rufii, 2015). According to Nilasari, Djatmika, \& Santoso, (2016) module is part of instructional materials packaged as a whole and systematically, that obtaining a set of the planned learning experience and designed to help students master specific learning objectives. A module as learning material in the classroom should provide effectiveness in primarily learning activities on the students learning outcomes (Khasanah, Sajidan, \& Widoretno, 2017; Osman \& Vebrianto, 2005). The education curriculum in Indonesia, especially in primary school, stated that the utilizing of thematic learning material will help students to achieve their learning objective. Thematic learning is considered as efficient as the students taught to learn in coherent context and holistic way, as well as associate the concepts they learned with their surrounding and real-life examples (Min, Rashid, \& Nazri, 2012; Retnawati, Munadi, Arlinwibowo, Wulandari, \& Sulistyaningsih, 2017). Thus, the development of thematic learning module becomes one of the important developments to empower effectiveness and the quality of students' learning outcomes.

However, the effectiveness of the learning modules is also influenced by the syntax of the learning model used. Some research showed that learning models that utilize problems around students' real-life help them to achieve their learning goals, such as problem-based learning. According to Palennari (2016) problem based learning force students to think and learn. The syntax of this learning model contains problem orientation, student orientation, problem investigation, present the results of problem-solving, and analyze and evaluate the results of problem-solving (Arends, 2012). In the investigation phase of the problem, students need a skill in thinking, one of which is critical thinking skills. Problem-based learning provides conducive classroom atmosphere because of student-centered learning, the student is able to think critically (Haseli \& Rezaii, 2013; Tiruneh, Verburgh, \& Elen, 2014). According to Irawan \& Febriyanti (2016) critical thinking is a skill that one has to effectively solve a problem with the true reason that can help one to analyze, evaluate and determine decisions about what you have done. Learning conducted by problem-based learning has a syntax similar with the indicators of critical thinking skills that are oriented to empower students' skill to analyze problems and be able to evaluate the decisions (Facione, 2011). It is to train students' skill in developing the idea that they have, and shape their character skilled in critical thinking (Cargas, Williams, \& Rosenberg, 2017; Ulger, 2018).

Regarding that situation, this study aims to develop problem-based thematic learning module for primary student, especially in the fifth grader. The module was developed based on the integration of several materials arranged in a unified, integrated and planned (Muhson, 2009). The problem-based thematic learning module was compiled with the development of the net model theme (webbed). The effectiveness of the developed module was determined by measuring students' critical thinking skills.

\section{METHOD}

This research and development ( $R \& D$ ) were conducted based on Borg and Gall model (Gall, Gall, \& Borg, 2007) which is comprised of ten stages. Due to time and cost constraints, this study is limited only to stage nine.

\section{Stage 1: Research and data collection}

The preliminary research and data collection conducted in primary school in Surakarta, Central Java, Indonesia. The student and teacher need assessment and observation technique was used to collect information.

\section{Stage 2: Planning the educational product}

In this stage includes: 1) estimating funding, personnel and time; 2) formulate validator qualification; and 3) compiling research instrument, consisting of students' questionnaire, students' critical thinking test (multiple choice and essay), and questionnaire of material, media, learning evaluation and strategy expert.

\section{Stage 3: Developing the product's preliminary form}

In the third stage, the preliminary form of the product was developed. It was a prototype draft of the problem-based thematic learning module. 


\section{Stage 4: Initial field-testing}

The initial field-testing was conducted by assessing the module by experts. There were four experts to assess the module including material expert, media expert, learning evaluation expert, and learning strategy expert. They are experts who hold doctoral degrees and professors and practitioners of primary school teachers who have experience in their field. Each expert was asked to evaluate the module design so that weaknesses designed module can be improved.

\section{Stage 5: The first revision of main product}

At this stage, the designed module gets a major revision to improve the product based on input from experts, especially in the module weaknesses part.

\section{Stage 6: Main field-testing}

The main field-testing was conducted by involving teacher (as practitioners) and ten students of the fifth grader in SDN (Sekolah Dasar Negeri or State Primary School) 1 of Kleco, Surakarta, Central Java, Indonesia. Then, the students' response to the designed module was measured using a questionnaire.

\section{Stage 7: Operational product revision}

Based on the students' response in the main field-testing, the designed module gets some revision in order to make the module more feasible to use.

\section{Stage 8: Operational field testing}

The operational field-testing was conducted with a larger participant, as many as 33 of fifth grade students in SDN 1 of Kleco. In this stage, the pre-experimental research design was used to find out the improvement of students' critical thinking skill. The data gained was analyzed using paired sample t-test using the SPSS version 20 program assistance (significance $5 \%$ ). Before the paired sample t-test was performed, the data were tested using the classical assumption test, namely the Kolmogorov-Smirnov test to find out the normality of data distribution and the Levene test to determine the difference of variances among the data.

\section{Stage 9: Final product revision}

The final module revision was carried out based on the result of operational field testing which has been generated from pre-experimental research.

\section{RESULTS AND DISCUSSION}

\section{Research and data collection}

Based on the need assessment result showed that students still find difficulties in studying the books due to general displaying material, the material discussion is less depth, so they feel hard to achieve the learning outcomes. The school applies students' book subsidies from the government and there is not another supporting book yet. On the other hand, the observation results showed that teacher also finds difficulties in presenting material to students due to the discussion material in the book is less understandable. Therefore, the teacher was required to seek additional reference material which is appropriate to help the student achieve their competences. Besides students' books are not led to the syntax of a learning model so that teachers cannot accommodate the learning process which refers to student-centered learning.

Teacher and learning activities in the classroom are dominated by conventional teacher-centered learning; this is the impact of providing less support material. The teacher should give more guidance and explanation of the material in each learning activity. The limitations in providing teaching materials in student books have an impact on student activities in the classroom. Students are not accommodated to practice their critical abilities. According to Broom (2011) and Zetriuslita, Ariawan, and Nufus (2016) the critical abilities including observation, analysis, interpretation, reflection, evaluation, inference, explanation, problem-solving, and decision making.

\section{Planning the educational product}

The results of this stage were: 1) the research and development required 9 months since the initial data collection until final product revision; 2) the product validators were consisted of four expert, namely material expert, media expert, learning evaluation expert and learning strategy expert; and 3) the research instruments were consisting of students' questionnaire, students' critical thinking test (multiple choice and essay), and questionnaire of each expert. The planning stage also has the purpose of determining the content of the themes used in the module developed. Modules developed are tailored to the competencies that must be achieved by students and in line with problem-based learning models. 


\section{Developing the product's preliminary form}

The thematic learning module was developed based on problem-based learning syntax. According to Johnson and Hayes (2015) and Simone (2014) problem-based learning is a pedagogical approach that provides opportunities for teachers and students to meet the demands of 21 st-Century education reformation that is expected to have solid content and involved knowledge in analyzing and solving problems. In problembased learning, studying the breadth of content material, factual knowledge acquisition because the emphasis is on the depth of content and high-level thinking (Gingerich, Mader, \& Payne, 2012; Xue et al., 2013). Learning by using problem interacts students more productive because students are allowed to choose their topics, students tend to make best efforts to ensure the success of the final performance (Treadwell, 2018). Problembased learning facilitates the direct reasoning and problem solving so that students can train their critical thinking (Ahrari, Samah, Hassan, Wahat, \& Zaremohzzabieh, 2016; Habimana \& Stambach, 2015; Novianto \& Mustadi, 2015). Critical thinking skills are very crucial in receiving and well comprehend in learning (Bahmani, 2016). Furthermore, critical thinking skills are needed to solve problems to the students both in learning and in their daily lives (Chukwuyenum, 2013; Mosher \& Desrochers, 2014; Wilkin, 2017).

Problem-based thematic learning module was developed based on ecosystem sub-themes which consist of six lessons (Figure 1). By utilizing problem in ecosystem teacher can explore students' potential to solve a real problem in the classroom. According to Cargas et al. (2017) and Goldstein, Burke, Getz, and Kennedy (2011) bringing a real-life problem to the classroom will help student active in discussions, training students to communicate well, and help them understand the difficult concepts. Some studies also state that problembased learning as one of student-centered learning model can involve students' active in the learning process (Efendioglu, 2015; Hamburg \& Vladut, 2016). The problem used will create a better learning atmosphere which can encourage the student to solve the problem in various ways in collaborative (Gallagher, Stepien, \& Rosenthal, 1992; Siew \& Mapeala, 2016). In line with Vygotsky's learning theory states that social interaction with other friends, triggering the formation of ideas new and enrich the intellectual development of students (Zhou \& Brown, 2015). The integration of problem-based learning syntax in the module can help teacher to accommodate students' critical thinking skills. Some studies revealed that problem-based learning can train students' critical thinking skills (Noprianda, Noor, \& Zulfiani, 2016; Schoenberger-Orgad \& Spiller, 2014). There are five students' activities in each lesson, namely: 1) observing, 2) reading, 3) conducting discussions, 4) finding out, and 5) trying (Figure 2). At the end of each lesson, there is an assessment sheet for the student (Figure 3).

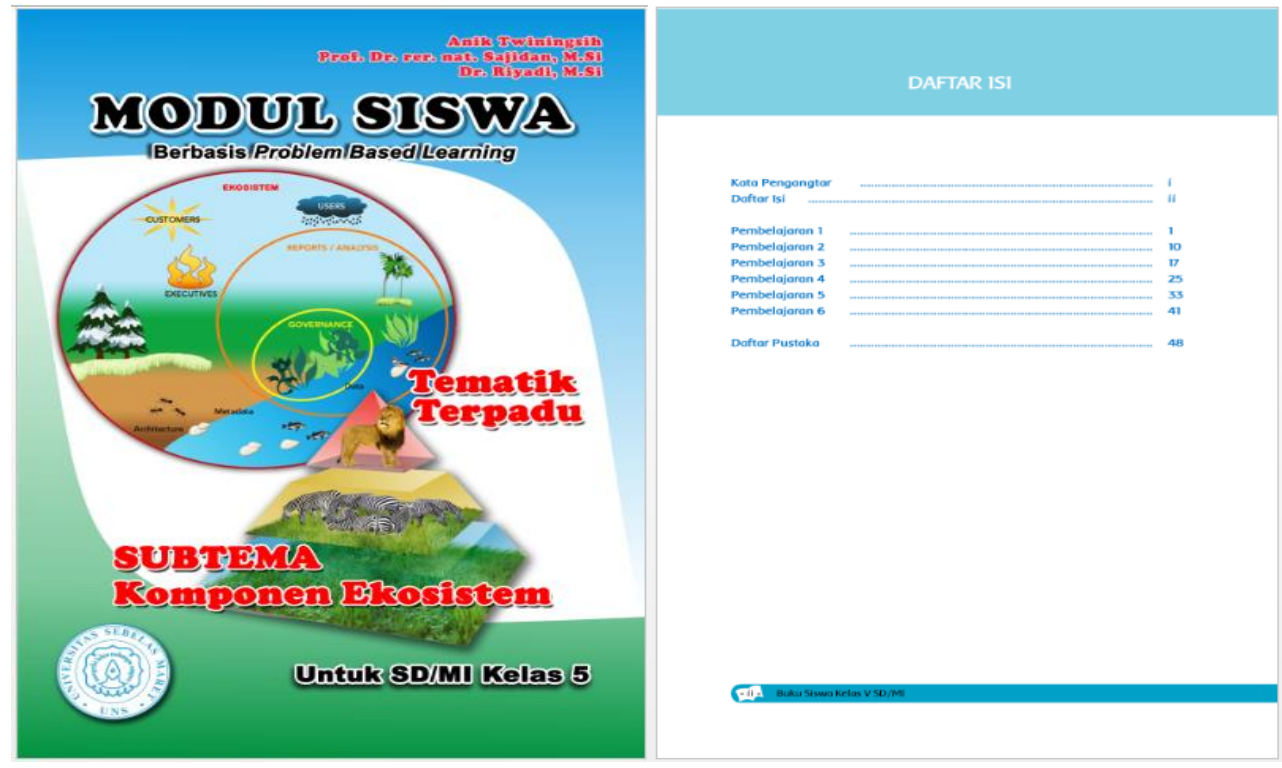

Figure 1. The cover page view (left) and the content list which listed six lesson in the module (right)

\section{Initial field-testing}

The initial field-testing was conducted by the validators who consist of four experts, namely material expert, media expert, learning evaluation expert and teaching strategy expert. They are experts who hold doctoral degrees and professors and practitioners of primary school teachers who have experience in their field. The results of the expert testing of the designed module can be seen in Table 1. The validation result showed that the material expert validation was $73 \%$, the media expert was $85 \%$, the learning evaluation was $94 \%$, and the 
learning strategy was $92 \%$. The problem-based thematic learning module can be categorized as good criteria so that the product test can be continued by improving some revision from the validator.

Table 1. Initial field-testing result.

\begin{tabular}{clc}
\hline No & Validator & Validation Result (\%) \\
\hline 1 & Material expert & 73 \\
2 & Media expert & 85 \\
3 & Learning evaluation expert & 94 \\
4 & Learning strategy expert & 92 \\
\hline & Average & 86
\end{tabular}

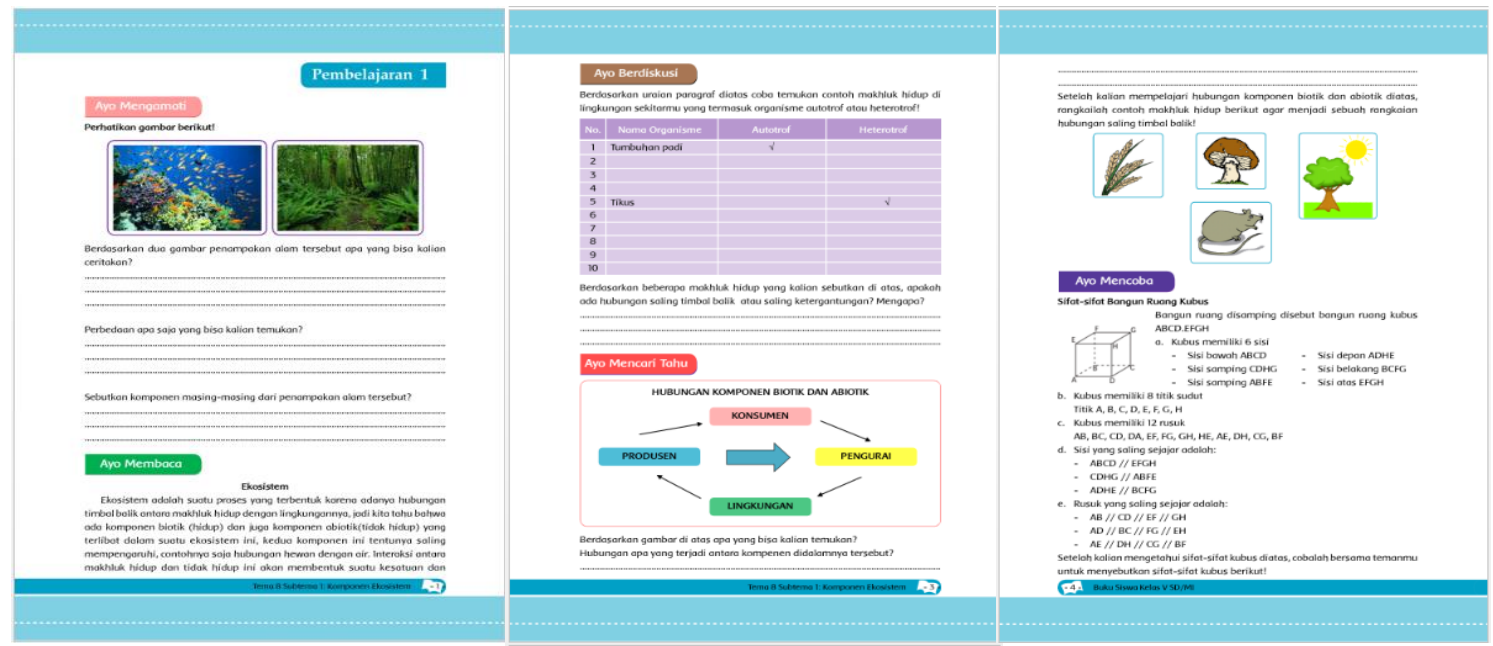

Figure 2. The students activities in lesson 1 consist of five activities: 1) observing (let's observe), (2) reading (let's read) (left), (3) conducting discussions (let's discuss), (4) finding out (let's find out) (center), and (5) trying (let's try)(right)

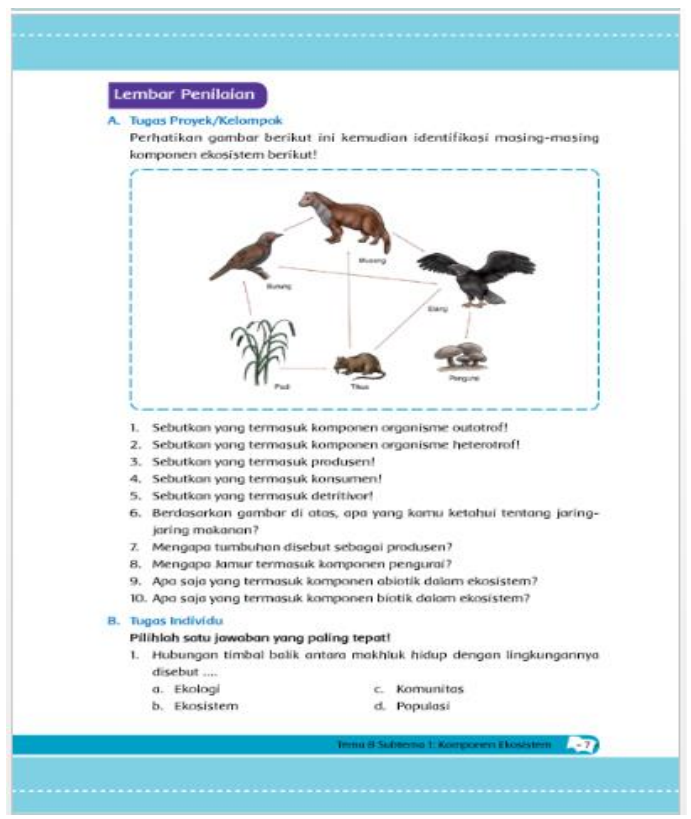

Figure 3. The assessment sheet page for student.

The first revision of main product

In this stage, there were some revisions to the module based on the initial field test. Based on the assessment of material experts, there were several revisions related to misconceptions in the student reading part. According to media experts, there was some image which not clearly visible. In addition, there are some parts that require more contrasting colors to attract students' attention. The learning evaluation experts suggest adding group assignments to the student assessment sheet. On the other hand, the learning strategy experts requested a consistency of student activities in each lesson in the module. 


\section{Main field-testing}

The results of practitioners and small group students testing were based on suggestions and inputs from trial subjects. The advice from practitioners and students, in general, can be seen in Table 2. Most of the student gives a positive response and feel interested in the designed module.

Table 2. Advice and suggestion of main field test participants

\begin{tabular}{ccc}
\hline Trial Subject & Advice and Suggestion & Result \\
\hline Practitioner I & - & No revision \\
Practitioner II & Improvement of lesson learn writing & Revision \\
Small Trial Result & - & No revision \\
\hline
\end{tabular}

\section{Operational product revision}

The revision of operational products is a made revision after the product is assessed by practitioners and students through small group test. The revised aspects are based on suggestions from trial subjects (Table 2). According to practitioner II, at the end of each lesson in the module, students are given the opportunity to write learned lessons obtained.

\section{Operational field-testing}

The purpose of operational field-testing was to find out the effectiveness of the module being developed. The problem-based thematic learning module was applied in 33 of fifth grade students in SDN 1 of Kleco. The product testing was carried out in accordance with the syllabus and lesson plans that have been prepared by the teacher in six lessons $(6 \times 35$ minutes). Before the lesson conducted, the students were given a pre-test. While at the end of the sixth lesson, they were given a post-test. The results of measurement of critical thinking skills in the pre-test and post-test are shown in the Table 3.

Table 3. The score of critical thinking skills

\begin{tabular}{cccc}
\hline Test Score & N & Mean & Standard Deviation \\
\hline Pre-test & \multirow{2}{*}{33} & 68.18 & 8.083 \\
Post-test & \multirow{2}{*}{84.61} & 10.070 \\
\hline
\end{tabular}

Based on Table 3, the post-test mean (84.61) is greater than the pre-test (68.18). After that, the result of the Kolmogorov-Smimov test to find out whether the data is normally distributed or not can be seen in Table 4. The results showed that Sig. (2-tailed) in pre-test $0.432>0.05$, it means that data is normally distributed. As well as the pre-test data, the post-test data also normally distributed with the Sig. (2-tailed) is $0.750(>0.05)$.

Table 4. The results of Kolmogorov-Smirnov test

\begin{tabular}{ccc}
\hline Test & Sig. & Conclusion \\
\hline Pre-test & 0.432 & Data distribution is normal \\
Post-test & 0.750 & Data distribution is normal \\
\hline
\end{tabular}

Table 5 showed the result of the paired sample t-test by comparing the critical thinking skills score between the pre-test and post-test.

Table 5. The result of paired sample t-test

\begin{tabular}{ccccc}
\hline Pair & $\mathbf{N}$ & $\mathbf{t}$ statistic & $\mathbf{d f}$ & $\mathbf{t}_{\text {table }}$ (2-tailed with $\left.\boldsymbol{\alpha}=\mathbf{0 . 0 5}\right)$ \\
\hline Pre-test - post-test & 33 & -4.310 & 32 & -2.042 \\
\hline
\end{tabular}

The results of the paired sample t-test in Table 5 showed that the obtained $t$ statistic (2-tailed) $-4.310<$ 2.042 (t table). This result showed that the post-test critical thinking skills significantly differed from the pre-test. Thus, it can be concluded that the problem-based thematic learning module was effectively improved students' critical thinking skills. Learning by using ecosystem problem-based thematic learning module conducted was proven effective to empower students' critical thinking skills. According to Nargundkar, Samaddar, and Mukhopadhyay (2014) and Simone (2014) it can be caused by the characteristics and syntax of Problem-based learning which may stimulate thinking skills, especially critical thinking skills of students. Okubo et al. (2016) added that problem-based learning is innovative learning to develop students' skill so that the learning more effective than using conventional methods for implementing and developing knowledge in solving complex problems, as well as to develop students' critical thinking skills more advanced and independent learning skills.

Ecosystem taught with a problem-based learning model will involve giving the orientation of the problems to students, organizing students to examine, assisting with the investigation independently and groups, develop and present work and exhibiting, analyze and evaluate the process of overcoming the problem (Arends, 2012). 
Learning ecosystems on the learning orients students on emerging issues observed, such as by drawing seawater ecosystems and tropical forests. Students also discuss the autotroph and heterotroph organisms and their role in the environment. Figuring out the relationship between abiotic and biotic components will train the students' analysis skill. According to Cochrane et al. (2004) and Zangori and Forbes (2015) this activity leads to the improvement of students' critical thinking skills. And then students discuss in the group the food web and constituent biotic and abiotic components in the environment. Davies, Earle, McMahon, Howe, and Collier (2017) underlined the collaborative discussion between students can improve their ability to communicate well and find the problem-solving.

Understanding of the basic concepts of ecosystems by using module will improve the thinking skills of students (Fahim \& Pezeshki, 2012; Khasanah et al., 2017). Students were more interested in learning about the ecosystem material in the problem-based thematic learning module in the learning process. The teacher can facilitate learning and provide motivation to learn the ecosystem using problem-based learning model (Ismail, Harun, Zakaria, \& Salleh, 2018; Kong, Qin, Zhou, Mou, \& Gao, 2014; Simamora, Simamora, \& Sinaga, 2017; Sulaiman \& Eldy, 2014). Problem-based learning in the classroom provides reading, writing, speaking, and discussing critically to improve the critical thinking skills of students (Chaijaroen, Kanjug, \& Samat, 2012; Chen \& Osman, 2017; Fahim \& Pezeshki, 2012). It can train critical thinking skills of students more optimal and facilitates them to make reasoning as well as solving the problem which provides student-centered learning activities (Ahrari et al., 2016; Habimana \& Stambach, 2015). Utilizing open-ended problems can enhance students' critical thinking skills by giving them opportunities to actively participate, express his ideas in their own way (Jamiah, 2012; Ku, Lee, \& Ellis, 2017; Nagge, Killeen, \& Jennings, 2018; Nargundkar et al., 2014). The students will also familiarize themselves to provide evidence of the problems solving (Mudrikah, 2016; Rosdiana, Yuniarsih, \& Waspada, 2018). Students can receive and gather information well in problem-based learning to improve their critical thinking skills (Bahmani, 2016).

\section{Final product revision}

Based on the operational field test results there is no suggestion from the participants of the operational field test. During the learning process using problem-based thematic learning module, students feel comfortable and easy in understanding the materials. Therefore, the module was feasible to use.

\section{CONCLUSION}

The problem-based thematic learning module with ecosystem theme is qualified and deserved to be applied at school. The results also showed that the students' post-test score of critical thinking skills significantly differed from their pre-test score. Therefore, the developed module can improve student critical thinking skills effectively. For further research, it is suggested that the teacher should apply a mixed method of teaching as it helps to strengthen students' critical thinking skills.

\section{ACKNOWLEDGMENT}

Authors would like to express deep gratitude to Head of SDN 1 of Kleco, Surakarta, Central Java, Indonesia, also teacher and students in the school for facilitating this research. Our gratitude also goes to all people who have assisted us.

\section{REFERENCES}

Ahrari, S., Samah, B. A., Hassan, M. S. H. Bin, Wahat, N. W. A., \& Zaremohzzabieh, Z. (2016). Deepening critical thinking skills through civic engagement in Malaysian higher education. Thinking Skills and Creativity, 22, 121-128. doi: https://doi.org/10.1016/j.tsc.2016.09.009

Arends, R. I. (2012). Learning to teach (9th ed.). Retrieved from http://onlinelibrary.wiley.com/doi/10.1002 /cbdv.200490137/abstract

Bahmani, S. (2016). Improved critical thinking in students using current events journaling. International Journal of Sociology and Social Policy, 36(3/4), 190-202. doi: https://doi.org/10.1108//JSSP-04-20150038

Broom, C. (2011). From critical thinking to critical being. ENCOUNTER: Education for Meaning and Social Justice, 24(2), 16-27. Retrieved from https://great-ideas.org/Encounter/Broom242.pdf

Cargas, S., Williams, S., \& Rosenberg, M. (2017). An approach to teaching critical thinking across disciplines using performance tasks with a common rubric. Thinking Skills and Creativity, 26, 24-37. doi: https:/l 


\section{doi.org/10.1016/j.tsc.2017.05.005}

Chaijaroen, S., Kanjug, I., \& Samat, C. (2012). The study of learners' critical thinking potential, learning with innovation enhancing thinking potential. Procedia - Social and Behavioral Sciences, 46, 3415-3420. doi: https://doi.org/10.1016/j.sbspro.2012.06.076

Chen, C. W. C., \& Osman, K. (2017). Cultivating marginalized children's scientific literacy in facing the challenges of the 21st century. K-12 STEM Education, 3(1), 167-177. doi: https://doi.org/10.14456/k12 stemed.2017.3

Chukwuyenum, A. N. (2013). Impact of critical thinking on performance in mathematics among senior secondary school students in Lagos State. IOSR Journal of Research \& Method in Education (IOSRJRME), 3(5), 18-25. Retrieved from http://www.iosrjournals.org/iosr-jrme/papers/Vol-3\%20lssue-5/D0 351825.pdf

Cochrane, K. L., Augustyn, C. J., Cockcroft, A. C., David, J. H. M., Griffiths, M. H., Groeneveld, J. C., ... Tarr, R. J. Q. (2004). An ecosystem approach to fisheries in the southern Benguela context. African Journal of Marine Science, 26(1), 9-35. doi: https://doi.org/10.2989/18142320409504047

Davies, D. J., Earle, S., McMahon, K., Howe, A., \& Collier, C. (2017). Development and exemplification of a model for teacher assessment in primary science. International Journal of Science Education, 39(14), 1869-1890. doi: https://doi.org/10.1080/09500693.2017.1356942

Efendioglu, A. (2015). Problem-based learning environment in basic computer course: Pre-service teachers' achievement and key factors for learning. Journal of International Education Research, 11(3), 205-216. doi: https://doi.org/10.19030/jier.v11i3.9372

Facione, P. A. (2011). Critical thinking : What it is and why it counts. Millbrae, CA: Measured Reasons and The California Academic Press. Retrieved from http://www.student.uwa.edu.au/_data/assets/ pdf_file/0003/1922502/Critical-Thinking-What-it-is-and-why-it-counts.pdf

Fahim, M., \& Pezeshki, M. (2012). Manipulating critical thinking skills in test taking. International Journal of Education, 4(1), 153-160. doi: https://doi.org/10.5296/ije.v4i1.1169

Gall, M. D., Gall, J. P., \& Borg, W. R. (2007). Educational research: An introduction, 8th edition. United State: Pearson. Retrieved from https://www.pearson.com/us/higher-education/program/Gall-EducationalResearch-An-Introduction-8th-Edition/PGM63179.html

Gallagher, S. A., Stepien, W. J., \& Rosenthal, H. (1992). The effects of problem-based learning on problem solving. Gifted Child Quarterly, 36(4), 195-200. doi: https://doi.org/10.1177/001698629203600405

Gingerich, A., Mader, H., \& Payne, G. W. (2012). Problem-based learning tutors within medical curricula: An interprofessional analysis. Journal of Interprofessional Care, 26(1), 69-70. doi: https://doi.org/10.3109 /13561820.2011.613494

Goldstein, L. B., Burke, B. L., Getz, A., \& Kennedy, P. A. (2011). Ideas in practice: Collaborative problembased learning in intermediate algebra. Journal of Developmental Education, 35(1), 26-37. Retrieved from https://www.questia.com/read/1P3-2604132651/ideas-in-practice-collaborative-problem-basedlearning

Habimana, O., \& Stambach, A. (2015). Kung Fu as critical thinking: An ethnographic analysis. Journal of Philosophy in Schools, 2(1), 56-70. doi: https://doi.org/10.21913/JPS.v2i1.1102

Hamburg, I., \& Vladut, G. (2016). PBL - Problem based learning for companies and clusters. Transportation Research Procedia, 18, 419-425. doi: https://doi.org/10.1016/j.trpro.2016.12.055

Haseli, Z., \& Rezaii, F. (2013). The effect of teaching critical thinking on educational achievement and test anxiety among junior high school students in Saveh. European Online Journal of Natural and Social Sciences, 2(2), 168-175. Retrieved from http://european-science.com/eojnss/article/view/151/pdf

Irawan, A., \& Febriyanti, C. (2016). Penerapan strategi pembelajaran kontekstual untuk meningkatkan kemampuan berpikir kritis matematika. Jurnal IImu Pendidikan, 22(1), 9-17. doi: https://doi.org/10.179 77/jip.v22i1.8639

Ismail, N. S., Harun, J., Zakaria, M. A. Z. M., \& Salleh, S. (2018). The effect of mobile problem-based learning application DicScience PBL on students' critical thinking. Thinking Skills and Creativity, 28, 177-195. doi: https://doi.org/10.1016/j.tsc.2018.04.002

Jamiah, Y. (2012). Internalisasi nilai-nilai berpikir kritis melalui pengembangan model pembelajaran konsep matematika kreatif pada pendidikan anak usia dini. Jurnal Pendidikan Dan Pembelajaran, 19(2), 229236. Retrieved from http://journal.um.ac.id/index.php/pendidikan-dan-pembelajaran/article/view/3402/ 621

Johnson, M., \& Hayes, M. J. (2015). A comparison of problem-based and didactic learning pedagogies on an 
electronics engineering course. International Journal of Electrical Engineering Education, 53(1), 3-22. doi: https://doi.org/10.1177/0020720915592012

Khasanah, A. N., Sajidan, \& Widoretno, S. (2017). Effectiveness of critical thinking indicator-based module in empowering student's learning outcome in respiratory system study material. Jurnal Pendidikan IPA Indonesia, 6(1), 187-195. doi: https://doi.org/10.15294/jpii.v6i1.8490

Kong, L.-N., Qin, B., Zhou, Y., Mou, S., \& Gao, H.-M. (2014). The effectiveness of problem-based learning on development of nursing students' critical thinking: A systematic review and meta-analysis. International Journal of Nursing Studies, 51(3), 458-469. doi: https://doi.org/10.1016/j.jinurstu.2013.06.009

Koparan, T. (2017). Analysis of teaching materials developed by prospective mathematics teachers and their views on material development. Malaysian Online Journal of Educational Technology, 5(4), 8-28. Retrieved from https://files.eric.ed.gov/fulltext/EJ1156942.pdf

Ku, K. Y. L., Lee, V. S. L., \& Ellis, J. W. (2017). Using artwork as problem context in generic critical thinking instruction: A strategy for thoughts. Thinking Skills and Creativity, 25, 53-59. doi: https://doi.org/10.1016 /j.tsc.2017.07.001

Min, K. C., Rashid, A. M., \& Nazri, M. I. (2012). Teachers' understanding and practice towards thematic approach in teaching Integrated Living Skills (ILS) in Malaysia. International Journal of Humanities and Social Science, 2(23), 273-281. Retrieved from http://www.ijhssnet.com/journals/Vol_2_No_23_Decem ber_2012/31.pdf

Mosher, H. R., \& Desrochers, M. (2014). The effects of information regarding sustainability issues and behavioral self-management instruction on college students' energy conservation. Journal of Sustainability in Higher Education, 15(3), 359-370. doi: https://doi.org/10.1108/IJSHE-03-2012-0027

Mudrikah, A. (2016). Problem-based learning associated by Action-Process-Object-Schema (APOS) theory to enhance students' high order mathematical thinking ability. International Journal of Research in Education and Science, 2(1), 125-135. Retrieved from https://files.eric.ed.gov/fulltext/EJ1105129.pdf

Muhson, A. (2009). Peningkatan minat belajar dan pemahaman mahasiswa melalui penerapan problembased learning. Jurnal Kependidikan, 39(2), 171-182. doi: https://doi.org/10.21831/jk.v39i2.212

Nagge, J. J., Killeen, R., \& Jennings, B. (2018). Using a course pilot in the development of an online problembased learning (PBL) therapeutics course in a post-professional PharmD program. Currents in Pharmacy Teaching and Learning, 10(2), 231-234. doi: https://doi.org/10.1016/j.cptl.2017.10.005

Nargundkar, S., Samaddar, S., \& Mukhopadhyay, S. (2014). A guided problem-based learning (PBL) approach: Impact on critical thinking. Decision Sciences Journal of Innovative Education, 12(2), 91-108. doi: https://doi.org/10.1111/dsji.12030

Nilasari, E., Djatmika, E. T., \& Santoso, A. (2016). Pengaruh penggunaan modul pembelajaran kontekstual terhadap hasil belajar siswa kelas V Sekolah Dasar. Jurnal Pendidikan: Teori, Pendidikan, Dan Pengembangan, 1(7), 1399-1404. doi: https://doi.org/10.17977/jp.v1i7.6583

Noprianda, M., Noor, M. F., \& Zulfiani. (2016). Keterampilan berpikir kritis siswa model pembelajaran problem based learning dan sains teknologi masyarakat pada konsep virus. EDUSAINS, 8(2), 182-191. doi: https://doi.org/10.15408/es.v8i2.3892

Novianto, A., \& Mustadi, A. (2015). Analisis buku teks muatan tematik integratif, scientific approach, dan authentic assessment sekolah dasar. Jurnal Kependidikan, 45(1), 1-15. doi: https://doi.org/10.21831/jk. v45i1.7181

Okubo, Y., Ishiguro, N., Suganuma, T., Nishikawa, T., Takubo, T., Kojimahara, N., ... Yoshioka, T. (2016). Team-based learning, a learning strategy for clinical reasoning, in students with problem-based learning tutorial experiences. The Tohoku Journal of Experimental Medicine, 240(2), 181-181. doi: https://doi. org/10.1620/tjem.240.181

Osman, K., \& Vebrianto, R. (2005). Fostering science process skills and improving achievement through the use of multiple media. Journal of Baltic Science Education, 12(2), 191-204. Retrieved from www.scientiasocialis.It/jbse/files/pdf/vol12/191-204.Osman_JBSE_Vol.12.2.pdf

Palennari, M. (2016). Pengaruh pembelajaran integrasi problem based learning dan kooperatif jigsaw. Jurnal IImu Pendidikan, 22(1), 36-45. doi: https://doi.org/10.17977/jip.v22i1.8656

Retnawati, H., Munadi, S., Arlinwibowo, J., Wulandari, N. F., \& Sulistyaningsih, E. (2017). Teachers' difficulties in implementing thematic teaching and learning in elementary schools. The New Educational Review, 48, 201-212. doi: https://doi.org/10.15804/tner.2017.48.2.16

Rosdiana, G. C., Yuniarsih, T., \& Waspada, I. (2018). The effect of implementation problem based learning method towards students' critical thinking skills moderated by self regulated learning on basic 
competency analyzing international trade. International Journal of Educational Research, 2(3), 15-26. Retrieved from https://ephjournal.com/index.php/er/article/view/568

Rufii, R. (2015). Developing module on constructivist learning strategies to promote students' independence and performance. International Journal of Education, 7(1), 18-28. doi: https://doi.org/10.5296/ije.v7i1. 6675

Saglam, H. I. (2011). An investigation on teaching materials used in social studies lesson. TOJET: The Turkish Online Journal of Educational Technology, 10(1), 36-44. Retrieved from http://www.tojet.net/ articles/v10i1/1014.pdf

Schoenberger-Orgad, M., \& Spiller, D. (2014). Critical thinkers and capable practitioners. Journal of Communication Management, 18(3), 210-221. doi: https://doi.org/10.1108/JCOM-11-2012-0085

Siew, N. M., \& Mapeala, R. (2016). The effects of problem-based learning with thinking maps on fifth graders' science critical thinking. Journal of Baltic Science Education, 15(5), 602-616. Retrieved from http:// www.scientiasocialis.It/jbse/files/pdf/vol15/602-616.Siew_JBSE_Vol.15_No.5.pdf

Simamora, S. J., Simamora, R. E., \& Sinaga, B. (2017). Application of problem based learning to increase students ' problem solving ability on geometry in class X SMA Negeri 1 Pagaran. International Journal of Sciences: Basic and Applied Research (IJSBAR), 36(2), 234-251. Retrieved from http://gssrr. org/index.php?journal=JournalOfBasicAndApplied\&page=article\&op=view\&path $\% 5 B \% 5 \mathrm{D}=8100 \&$ path $\%$ $5 \mathrm{~B} \% 5 \mathrm{D}=3721$

Simone, C. De. (2014). Problem-based learning in teacher education: Trajectories of change. International Journal of Humanities and Social Science, 4(12), 17-29. Retrieved from http://www.ijhssnet.com/ journals/Vol_4_No_12_October_2014/3.pdf

Sulaiman, F., \& Eldy, E. F. (2014). Integrated PBL approach: Findings towards physics students' critical thinking. International Journal for Innovation Education and Research, 2(2), 75-81. Retrieved from www.ijier.net/index.php/ijier/article/download/148/79/\%0A

Tiruneh, D. T., Verburgh, A., \& Elen, J. (2014). Effectiveness of critical thinking instruction in higher education: A systematic review of intervention studies. Higher Education Studies, 4(1), 1-17. doi: https://doi.org/10. 5539/hes.v4n1p1

Treadwell, S. M. (2018). Making the case for project-based learning (PBL) in physical education. Jounal of Physical Education, Recreation \& Dance, 89(1), 5-6. doi: https://doi.org/10.1080/07303084.2018.13932 25

Ulger, K. (2018). The effect of problem-based learning on the creative thinking and critical thinking disposition of students in visual arts education. Interdisciplinary Journal of Problem-Based Learning, 12(1). doi: https://doi.org/10.7771/1541-5015.1649

Wilkin, C. L. (2017). Enhancing critical thinking: accounting students' perceptions. Education + Training, 59(1), 15-30. doi: https://doi.org/10.1108/ET-01-2015-0007

Williams, K. C., \& Williams, C. C. (2011). Five key ingredients for improving student motivation. Research in Higher Education Journal, 11, 1-23. Retrieved from http://scholarsarchive.library.albany.edu/math_fac_ scholarhttp://aabri.com/manuscripts/11834.pdf

Xue, H., Qian, J., Wang, L., Yuan, X., Chen, Y., Wu, W., ... Sun, K. (2013). 3C3R modified PBL pediatric teaching of Chinese medical students. PLOS ONE, 8(5), 1-9. doi: https://doi.org/10.1371/journal.pone. 0063412

Zangori, L., \& Forbes, C. T. (2015). Exploring third-grade student model-based explanations about plant relationships within an ecosystem. International Journal of Science Education, 37(18), 2942-2964. doi: https://doi.org/10.1080/09500693.2015.1118772

Zetriuslita, Ariawan, R., \& Nufus, H. (2016). Students' critical thinking ability: Description based on academic level and gender. Journal of Education and Practice, 7(12), 154-164. Retrieved from https://files.eric. ed.gov/fulltext/EJ1099476.pdf

Zhou, M., \& Brown, D. (Eds.). (2015). Educational learning theories: 2nd edition (2nd ed.). Georgia: GALILEO, University System of Georgia. Retrieved from https://oer.galileo.usg.edu/education-textbooks/1/ 